\title{
PENTINGNYA PENGAWASAN PARTISIPATIF DALAM MENGAWAL PEMILIHAN UMUM YANG DEMOKRATIS
}

\author{
Ratnia Solihah $^{1}$, Arry Bainus ${ }^{2}$ dan Iding Rosyidin ${ }^{3}$ \\ ${ }^{1}$ Departemen Ilmu Politik Fakultas Ilmu Sosial dan Ilmu Politik Universitas Padjadajran \\ ${ }^{2}$ Departemen Hubungan Internasional Fakultas Ilmu Sosial dan Ilmu Politik Universitas Padjadajran \\ ${ }^{3}$ Program Studi Ilmu Politik FISIP UIN Syarif Hidayatullah, Jakarta, Indonesia \\ E-mail: ratnia@unpad.ac.id
}

\begin{abstract}
ABSTRAK
Tulisan ini mengkaji tentang pentingnya pengawasan partisipatif dalam mengawal penyelenggaraan pemilu, yang bertujuan untuk menciptakan pemilu yang demokratis. Saat ini terdapat berbagai lembaga pengawas pemilu, antara lain Badan Pengawas Pemilu (Bawaslu) di tingkat pusat, Panitia Pengawas Pemiluu (Panwaslu) di tingkat Daerah, dan Dewan Kehormatan Penyelenggara Pemilu (DKPP) yang khusus menangani pelanggaran etik oleh penyelenggara pemilu. Namun dalam kenyataannya masih ditemui berbagai pelanggaran oleh berbagai pihak, sehingga pemilu dinilai kurang berintegritas dan kurang demokratis. Dengan dilibatkannya stakeholder dan masyarakat secara independen dalam mengawasi penyelenggaraan pemilu, diharapkan proses pemilu yang demokratis akan terwujud. Dengan menggunakan pendekatan kualitatif melalui studi literatur, tulisan ini membahas persoalan yang muncul dalam konteks pengawasan partisipatif, pengawasan partisipatif yang sudah dilakukan selama ini oleh lembaga pemantau pemilu maupun organisasi masyarakat sipil lainnya serta upaya yang dilakukan dalam pengawasan partisipatif untuk mengawal pemilu yang demokratis sesuai dengan peraturan perundang-undangan yang berlaku.
\end{abstract}

Kata kunci: Pengawasan Partisipatif, Pemilu, Demokratis

\section{ABSTRACT}

This paper examines the importance of participatory monitoring in overseeing the election, which aims to create democratic elections. Currently, there are various election supervisory bodies, such as the Central Election Supervisory Board (Bawaslu) at the central level, the Election Supervisory Committee (Panwaslu) at the regional level, and the Election General Electoral Council (DKPP) which deal specifically with ethical violations by election organizers. But in reality there are still various violations by various parties, so the election is considered less integrity and less democratic. With the involvement of stakeholders and the community independently in watching the elections, it is hoped that a democratic election process will be realized. This paper using a qualitative study to discusses issues that arise in the context of participatory monitoring, participatory oversight already undertaken by election observers and other civil society organizations as well as efforts taken in participatory monitoring to preserve democratic elections by current regulation.

Key words: participatory oversight, Electoral, Democratic

\section{PENDAHULUAN}

Demokrasi merupakan sistem politik yang memberikan ruang bagi keadilan dan persamaan bagi semua warga negara. Sistem ini menjadi pilihan paling populer yang digunakan negara-negara di dunia.

Beberapa lembaga internasional menawarkan sistem yang memungkinkan untuk melakukan kuantifikasi terhadap demokrasi. Freedom House sejak tahun 1972 melakukan pengukuran demokrasi dengan klasifikasi free countries, partly free countries, dan not free countrie (Badan Pusat Statistik, 2016: 147).
Berdasarkan Klasifikasi tersebut, Indonesia yang sebelumnya digolongkan sebagai negara dengan status partly free, sejak tahun 2008 telah digolongkan sebagai free countries. Dalam tren global yang dibuat Freedom House (2016) terlihat bahwa jumlah negara dengan status free countries persentasenya menurun pada tahun 2016 (Badan Pusat statistik, 2016: 148). Selain Freedom House, The Economist (2015) membuat pengukuran serupa tentang demokrasi dengan kategori full democracies, flawed democracies, hybrid regimes, serta authoritarian regimes (Badan Pusat Statistik, 2016: 149) yang juga mencantumkan ranking 
dari semua negara yang diukur. Pada Tahun 2007 Indonesia menempati ranking 65, turun menjadi peringkat 69 pada tahun 2008 dan naik menjadi peringkat 60 pada tahun 2010 dan menempati posisi 58 pada Tahun 2012 (Badan Pusat Statistik, 2016: 147).

Ciri paling mendasar dari sebuah negara demokrasi adalah keberadaan pemilihan umum (Pemilu). Sekalipun bukan satu-satunya aspek dalam demokrasi, namun Pemilu merupakan satu bagian yang sangat penting, karena Pemilu berperan sebagai mekanisme perubahan politik mengenai pola dan arah kebijakan publik dan/ atau mengenai sirkulasi elit secara periodik dan tertib (Surbakti dkk, 2008: 12).

Begitu juga dengan Indonesia, Pemilu dilaksanakan sebagai wujud dari demokrasi yang merupakan sarana dalam mengagregasi aspirasi yang ada di masyarakat yang sebelumnya diartikulasikan oleh partai politik sesuai dengan fungsinya.

Dengan berjalannya waktu, pemilu di Indonesia yang dimulai dari tahun 1955 sudah mengalami perkembangan yang cukup signifikan apabila kita melihatnya dari aspek pengawasan dalam pemilu. Pada Pemilu pertama Tahun 1955, belum dikenal istilah pengawasan pemilu. Karena pada masa itu telah ada kepercayaan (trust) antara seluruh peserta pemilu dengan warga negara terhadap penyelenggaraan pemilu yang pada saat itu dimaksudkan untuk membentuk lembaga parlemen yang disebut dengan Dewan Konstituante.

Pengawasan pemilu baru muncul dalam pelaksanaan pemilu tahun 1982, namanya adalah Panitia Pengawas Pelaksanaan Pemilihan Umum (Panwaslak Pemilu), yang terbentuknya dilatarbelakangi oleh ketidakpercayaan terhadap pemilu yang dianggap telah disetting oleh kekuatan rezim penguasa (Bawaslu RI, 2017). Kemudian pada Pemilu tahun 1987, protes terhadap pelanggaran dan kecurangan pemilih lebih banyak lagi, sehingga pemerintah dan DPR yang ketika itu didominasi oleh Golkar dan Angkatan Bersenjata Republik Indonesia merespon hal ini dengan gagasan untuk memperbaiki undang-undang yang bertujuan untuk meningkatkan kualitas pemilu berikutnya. Pemerintah juga mengenalkan adanya badan baru yang akan terlibat dalam urusan pemilu sebagai pendamping Lembaga Pemilihan Umum (LPU).
Pada saat sekarang, yaitu era reformasi, tuntutan untuk pemilu yang jujur dan adil semakin tinggi, dibuktikan dengan semakin kuatnya legal formal pembentukan Badan Pengawas Pemilu (Bawaslu) di tingkat Pusat, di tingkat Provinsi sampai Pembentukan Panitia Pengawasan Pemilu di tingkat Kabupaten/ Kota yang awalnya adhoc saja maka diusulkan agar menjadi permanen (Suswantoro, 2016: $62)$.

Namun demikian, Bawaslu sebagai badan formal yang bertugas untuk mengawasi seluruh tahapan penyelenggaraan pemilu, masih mengalami berbagai kendala pengawasan.

Salah satu contoh masalah yang terkait dengan kendala pengawasan adalah adanya pelanggaran pilkada serentak 2015 sebagaimana dikemukakan oleh Peneliti Perkumpulan untuk Pemilu dan Demokrasi (Perludem), Khairunisa Nur Agustiyati, bahwa dari keseluruhan tahapan pilkada serentak 2015 ditemukan 140 pelanggaran yang terbagi ke dalam lima kategori diantaranya kekerasan pelaksanaan pilkada, logistik pilkada, pelanggaran pidana dalam pelaksanaan pilkada, pelanggaran administrasi dan sengketa pencalonan. Pelanggaran pidana merupakan pelanggaran terbanyak dengan ditemukannya 54 temuan. Urutan kedua adalah logistik dengan 36 temuan, salah satu bentuk pelanggarannya adalah tidak disebarkannya undangan pemilihan formulir C6 untuk pemilih. Urutan ketiga adalah pelanggaran administrasi dengan 25 temuan, sedangkan pelanggaran kekerasan di urutan keempat dengan 13 temuan, dan sengketa pencalonan berada di urutan terakhir dengan 12 temuan. (Pasaribu, 2015).

Adanya kecenderungan pelanggaran di setiap pemilu salah satunya karena keterbatasan jumlah pengawas jika dilihat dari banyaknya Tempat Pemungutan Suara (TPS) yang ada. Pada pilpres 2014, dalam rangka pemberian dukungan administratif dan teknis operasional pengawasan Pemilu, Bawaslu, Bawaslu Provinsi, Panwaslu Kabupaten/Kota, Panwaslu Kecamatan, dan Pengawas Pemilu Luar Negeri telah membentuk sekretariat, dengan dukungan personil sebanyak248orang sekretariatBawaslu, 819 orang sekretariat Bawaslu Provinsi, 5.947 orang sekretariat Panwaslu Kabupaten Kota, 30.399 orang sekretariat Panwaslu Kecamatan, dan 29 orang sekretariat Pengawas Pemilu Luar Negeri (Bawaslu RI, 2014: 16). Sementara itu, saat pileg dan pilpres 2014 terdapat sebanyak 
545.803 TPS. (https://nasional.sindonews. com/ $\mathrm{read} / 1235166 / 12 / \mathrm{kpu}-$ tetapkan-pemilih-300orang-di-tiap-tps-1504070517) .

Dalam pemilu serentak yang akan diselenggarakan tahun 2019 terjadi penambahan TPS yang cukup signifikan. Apalagi dengan disusutkannya jumlah pemilih dari pemilu sebelumnya 500 orang pemilih menjadi 300 orang pemilih per TPS, sehingga total seluruh TPS di Indonesia pada pemilu serentak 2019 adalah sebanyak 800 ribuan, bahkan bisa lebih dari 800.000 (http://nasional.republika. co.id/ 29 Agustus 2017). Bertambahnya jumlah TPS tersebut harus diiringi oleh bertambahnya jumlah pengawas dalam pemilu serentak, yang tidak saja menjadi tugas Bawaslu dan Panwaslu di daerah, tetapi juga perlu adanya pengawasan dari pihak di luar lembaga pengawas pemilu tersebut. Oleh karenanya penting sekali untuk melibatkan seluruh pemangku kepentingan dan masyarakat dalam proses pengawasan ini.

Dengan dilibatkannya pemangku kepentingan (stakeholder) dan masyarakat secara independen dalam mengawasi penyelenggaraan pemilu, diharapkan akan menghasilkan pemilu yang berintegritas, dimana seluruh partisipan pemilu akan lebih merasa mawas diri dan memiliki kesadaran politik yang baik terhadap nilai-nilai kejujuran, keadilan dan demokratis terkait pemilu.

Beberapa tulisan tentang pengawasan dalam pemilu banyak dilakukan, antara lain tulisan tentang Fungsi dan Peran Panwaslu Dalam Sistem Pemilihan Umum di Indonesia (Kajian dari Aspek Yuridis) oleh J. Tjiptabudy. Dalam kajian tersebut, Panwas Pemilu mempunyai peranan yang penting dalam rangka mengawal pelaksanaan pemilu sesuai dengan peraturan perundang-undangan yang berlaku. Pentingnya peranan Pengawas Pemilu karena semua pengaduan haruslah melewati satu pintu yaitu Pengawas Pemilu.

Musfialdy dalam tulisannya yang berjudul Mekanisme Pengawasan Pemilu di Indonesia, membahas Mekanisme Kerja Pengawasan Pemilu mulai dari Pendaftaran partai Politik dan Verifikasi Partai Politik sampai dengan Rekapitulasi Penghitungan Perolehan Suara, yang menjadi tahapan bawaslu dan panwaslu dalam menjalankan tugas dan fungsinya berdasarkan UU No 10 Tahun 2008.

Kajian lainnya tentang pengawasan pemilu dilakukan oleh Perludem dengan judul
"Pelibatan dan Partisipasi Masyarakat dalam Pengawasan Pemilu." Pelibatan masyarakat menunjukkan satu kewajiban bawaslu sebagai fungsi yang terlembaga dalam pengawasan pemilu, sedangkan partisipasi masyarakat lebih pada penggunaan hak warga negara untuk mengawal hak pilihnya. namun, pelembagaan pengawasan itu tidak serta-merta mengambil hak warga negara untuk melakukan fungsi kontrolnya dalam menjaga suara atau kedaulatan rakyat.

Dalam tulisan ini, penulis mempertegas pentingnya pengawasan partisipatif, tidak saja dari masyarakat pemilih, namun dari berbagai pihak yang terkait (stakeholders) dan masyarakat sendiri.

Berdasarkan apa yang dikemukakan di atas, penulis tertarik untuk mengkaji pentingnya pengawasan partisipatif dalam mengawal pemilu yang demokratis, dengan membahas persoalan yang muncul dalam konteks pengawasan partisipatif, mengidentifikasi pengawasan partisipatif yang sudah dilakukan selama ini oleh lembaga pemantau pemilu maupun organisasi masyarakat sipil lainnya serta upaya yang dilakukan dalam pengawasan partisipatif untuk mengawal pemilu yang demokratis sesuai dengan peraturan perundang-undangan yang berlaku.

\section{METODE}

Kajian tentang Pentingnya Pengawasan Partisipatif dalam Mengawal Pemilihan Umum yang Demokratis memerlukan identifikasi dan pemahaman yang mendalam untuk melihat konteks politik yang melingkupi permasalahan penelitian dan proses yang terjadi dalam pengawasan partisipatif tersebut. Oleh karenanya, pendekatan penelitian yang digunakan adalah penelitian kualitatif dengan menggunakan studi literatur. Sebagaimana dikemukakan oleh Maxwell (1996:17-19), penelitian kualitatif antara lain ditujukan untuk memahami makna, memahami konteks partikular, mengantisipasi fenomena dan pengaruh yang tidak terantisipasi, serta memahami proses. Kajian ini bertujuan mengidentifikasi persoalan yang muncul dalam konteks pengawasan partisipatif, mengidentifikasi pengawasan partisipatif yang sudah dilakukan selama ini oleh lembaga pemantau pemilu maupun organisasi masyarakat sipil lainnya serta upaya 
yang dilakukan dalam pengawasan partisipatif untuk mengawal pemilu yang demokratis sesuai dengan peraturan perundang-undangan yang berlaku.

\section{HASIL DAN PEMBAHASAN}

\section{Bawaslu RI sebagai pengawal pemilu yang demokratis}

Parameter pemilu yang demokratis ditandai dengan adanya integritas proses penyelenggaraan pemilu dan integritas hasil pemilu (Suswantoro, 2016: 18). Integritas proses penyelenggaraan pemilu akan berhasil dicapai jika semua tahapan pemilu diselenggarakan menurut peraturan perundang-undangan yang berlaku, seperti Undang-Undang Pemilu dan Peraturan KPU, yang kesemuanya mengandung kepastian hukum. Semua ketentuan, baik Undang-undang Pemilu maupun turunannya di dalam Peraturan KPU tidak boleh menyimpang dari asas Luber Jurdil.

Adapun pengertian Luber Jurdil (Bawaslu, 2015: 12) adalah sebagai berikut:

1. Langsung berarti pemilih diharuskan memberikan suaranya secara langsung dan tidak boleh diwakilkan;

2. Umum berarti pemilihan umum dapat diikuti seluruh warga negara yang sudah memiliki hak menggunakan suara;

3. Bebas berarti pemilih diharuskan memberikan suaranya tanpa ada paksaan dari pihak mana pun;

4. Rahasia berarti suara yang diberikan oleh pemilih bersifat rahasia, hanya diketahui oleh si pemilih itu sendiri;

5. Jujur mengandung arti bahwa pemilihan umum harus dilaksanakan sesuai dengan aturan untuk memastikan bahwa setiap warga negara yang memiliki hak dapat memilih sesuai dengan kehendaknya, dan setiap suara pemilih memiliki nilai yang sama untuk menentukan wakil rakyat yang akan terpilih;

6. Adil adalah perlakuan yang sama terhadap peserta pemilu dan pemilih, tanpa ada pengistimewaan atau diskriminasi terhadap peserta atau pemilih tertentu. Asas jujur dan adil mengikat tidak hanya kepada pemilih atau peserta pemilu, tetapi juga kepada penyelenggara pemilu.

Signifikansi dari keberadaan lembaga pengawas pemilu seperti Bawaslu, sebagaimana yang diamanatkan oleh undang-undang adalah memastikan bahwa parameter pemilu yang demokratis baik dalam proses maupun hasil pemilu, serta asas-asas pemilu tersebut dapat berjalan dengan baik.

\section{Pemilu Demokratis}

Menurut Surbakti (2015:11), untuk mewujudkan pemilu demokratis, terdapat beberapa parameter, yaitu:

1. Kesetaraan antar warga negara, baik dalam pemungutan dan penghitungan suara maupun dalam alokasi kursi DPR dan DPRD dan pembentukan daerah pemilihan. Pemilu diselenggarakan karena yang diterapkan bukan demokrasi langsung, melainkan demokrasi perwakilan. Agar dapat berjalan, demokrasi perwakilan memerlukan rakyat sebagai pemilih berdaulat, sejumlah wakil/ kursi untuk tiap daerah pemilihan, dan partai politik atau calon sebagai peserta pemilu yang bersaing mendapat kepercayaan rakyat jadi wakil daerah pemilihan itu;

2. Kepastian hukum yang dirumuskan berdasarkan asas pemilu demokratis. Salah satu dimensi penyelenggaraan pemilu adalah kompetisi atau konflik merebut kursi. Agar berlangsung tertib, penyelenggaraan pemilu harusberdasarkanhukumberderajatkepastian tinggi. Agar pemilu yang diselenggarakan demokratis, hukum yang mengatur pemilu harus merupakan penjabaran asas pemilu demokratis: langsung, umum, bebas, rahasia, jujur dan adil, transparan dan akuntabel;

3. Persaingan bebas dan adil antar kontestan pemilu. Agar penyelenggara negara yang terpilih berasal dari partai atau calon terbaik, harus ada kompetisi bebas dan adil antarpartai/calon untuk meyakinkan rakyat memilih mereka. Para kontestan harus berangkat dan bersaing dari titik tolak sama sehingga yang terbaik yang akan terpilih;

4. Partisipasi seluruh pemangku kepentingan dalam seluruh rangkaian penyelenggaraan tahapan pemilu. Untuk menjamin agar rakyat berdaulat, peran warga negara dalam pemilu tak hanya memberi suara, tetapi juga melakukan berbagai peran berbeda pada seluruh tahap pemilu. Secara individu, kelompok, terorganisasi atau melembaga, rakyat perlu berperan dalam pendidikan pemilih, aktif sebagai anggota partai dalam membahas calon dan rencana kebijakan partai, melakukan kampanye mendukung 
atau menentang peserta pemilu tertentu, memantau pelaksanaan pemilu, mengawasi penyelenggaraan pemilu, memberitakan atau menyiarkan kegiatan pemilu melalui media massa, melakukan survei dan menyebarluaskan hasil survei tentang persepsi pemilih tentang peserta pemilu, serta melakukan dan menyebarluaskan hasil hitung cepat hasil pemilu. Rangkaian penyelenggaraan pemilu akan dipercaya rakyat dan peserta jika pemilu diselenggarakan badan yang tak hanya kompeten dan berkapasitas dalam bidang tugasnya, tetapi juga independen dan mengambil keputusan yang imparsial (tak memihak);

5. Badan penyelenggara pemilu yang profesional, independen dan imparsial. Badan penyelenggara pemilu dapat dikategorikan bertindak independen jika menyelenggarakan pemilu semata-mata berdasarkan peraturan perundang-undangan dan kode etik penyelenggara pemilu;

6. Integritas pemungutan, penghitungan, tabulasi dan pelaporan suara pemilu. Puncak rangkaian penyelenggaraan pemilu adalah pemungutan dan penghitungan suara. Karena itu, seluruh asas pemilu demokratis (langsung, umum, bebas, rahasia, jujur dan adil, transparan dan akuntabel) diterapkan pada rangkaian pemungutan, penghitungan, rekapitulasi hasil perhitungan suara, dan pelaporan hasil pemilu. Pemungutan, penghitungan, rekapitulasi hasil perhitungan suara, dan pelaporan hasil pemilu yang sesuai dengan asas pemilu demokratis dapat dikategorikan sebagai berintegritas;

7. Penyelesaian sengketa pemilu yang adil dan tepat waktu. Dalam penyelenggaraan pemilu sangat mungkin terjadi berbagai sengketa antara peserta dan penyelenggara ataupun pelanggaran berbagai ketentuan tentang pemilu oleh peserta/calon, penyelenggara, atau pemilih. Berbagai sengketa pemilu ini wajib diselesaikan dan berbagai pelanggaran ketentuan pemilu itu harus diputus.

Penyelesaian sengketa dan penegakkan peraturan pemilu akan mendatangkan rasa adil bila penyelesaian sengketa pemilu atau penegakkan peraturan pemilu diputuskan secara adil sesuai dengan jangka waktu yang ditentukan. Selain itu, sebagaimana poin 4, harus ada partisipasi dari seluruh pemangku kepentingan (stakeholders) dalam seluruh tahapan penyelenggaran pemilu. Partisipasi publik baik stakeholders maupun masyarakat secara independen tersebut menjadi salah satu upaya untuk menciptakan pemilu yang berintegritas, dimana pengawasan publik yang dilakukannya bertujuan untuk mengawal penyelenggaraan pemilu yang berintegritas.

Beberapa permasalahan pengawasan dalam pemilu adalah adanya beberapa fenomena maupun kasus yang sering terjadi dalam penyelenggaraan pemilu, antara lain pengawas pemilu yang tidak independen dan memihak pada salah satu calon/partai politik peserta pemilu, sehingga mengakibatkan adanya diskriminasi perlakuan terhadap calon/partai politik peserta pemilu terhadap pelanggaranpelanggaran yang terjadi.

Hal ini tentu saja akan menghasilkan pemimpin-pemimpin yang lahir dari proses demokrasi yang tidak berintegritas dimana asas Luber dan Jurdil tidak diamalkan dengan baik.

Untuk meminamilisir hal tersebut, salah satunya adalah melibatkan masyarakat dalam hal pengawasan pemilu tersebut, sehingga masyarakat ikut serta mengawal hak pilihnya bukan hanya menunggu hasil semata. Dengan adanya keterlibatan masyarakat maka kepercayaan masyarakat terhadap integritas proses dan hasil pemilu meningkat.

Pada prakteknya, di saat sekarang muncul gerakan masyarakat yang menjadi pengawas pemilu, yaitu Pemantau Pemilu dan pengawasan Partisipatif, sebagai berikut:

\section{Pemantau Pemilu}

Pemantau pemilu terdiri dari Lembagalembaga swadaya masyarakat atau CSO (Civil Society Organization) yang ikut mengawasi Tahapan penyelenggaraan Pemilu. Untuk pendaftaran pemantau pilkada serentak 2018 telah dibuka sejak 12 Oktober 2017, namun di beberapa kabupaten/kota sepi pendaftarnya. Pendaftaran pemantau pemilu yang sering terjadi sekarang adalah ketika dibuka pendaftaran untuk pemantau pemilu, seringkali tidak ada yang mendaftar khususnya di Kabupaten/Kota. Misalnya di Kabupaten Temanggung (http:// krjogja.com 15 Oktober 2017); Kabupaten Jombang sampai 10 Maret 20102018 belum 1 pun pemantau pemilu yang mendaftar (https:// faktualnews.co 9 Maret 2018); dan Kota Serang baru 1 pemantau pemilu yang mendaftar 
sampai tanggal 10 Februari 2018 (https:// www.kabar-banten.com 4 Februari 2018). Hal tersebut menyebabkan kurangnya pengawasan partisipatif terkait tahapan penyelenggaraan Pemilu. Sebagian besar mereka baru mendaftar menjelang hari $\mathrm{H}$ pemungutan Suara, padahal yang harus diawasi bukan lah hari pemungutan suara saja melainkan seluruh tahapan penyelenggaraan pemilu yang memungkinkan sekali untuk terjadinya pelanggaran baik dari penyelenggara pemilu maupun partai politik sebagai peserta pemilu.

Dalam Undang-Undang Pemilu No. 7 Tahun 2017, pendaftaran dan akreditasi pemantau pemilu berada pada wilayah kewenangan Badan Pengawas Pemilu. Ini berarti secara legalitas Pemantau Pemilu diperoleh dari Bawaslu, dimulai dari pelaporan hingga sanksi berlaku sama dan berjenjang, segala kewenangan terkait dengan Pemantau Pemilu berada di lembaga pengawas yaitu Badan Pengawas Pemilu (Bawaslu) dan berlaku sesuai tingkatannya (provinsi/kabupaten/kota). Hal ini juga baik untuk kemajuan pengawasan karena akan adanya sinergitas antara Bawaslu dengan pemantau pemilu sendiri khususnya terkait penetapan kode etik, hak dan kewajiban pemantau pemilu ini dan juga pelaporan. Setidaknya dengan lebih banyak mata yang memandang, maka partai politik dan penyelenggara pemilu akan lebih mawas diri dalam bekerja.

Pemantau pemilu memperkuat fungsi pengawasan Badan Pengawas Pemilu (Bawaslu) karena akan mendukung upaya-upaya dan kegiatan-kegiatan pengawasan yang dilakukan oleh Bawaslu. Dengan perubahan regulasi tersebut, maka lembaga-lembaga pemantau pemilu akan sangat membantu dan menunjang pengawasan yang dilakukan oleh Bawaslu.

Beberapa pemantau pemilu yang ada di Indonesia antara lain Lembaga Pemantau Pemerintahan Negara Kesatuan RI(LPPNKRI), Komite Independen Pemantau Pemilu (KIPP) Indonesia, Jaringan Pendidikan Pemilih untuk Rakyat (JPPR), Perkumpulan untuk Pemilu dan Demokrasi (Perludem), Peneliti Perkumpulan untuk Pemilu dan Demokrasi (Perludem), Jaringan Pendidikan Pemilih untuk Rakyat (JPPR), Komite Independen Pemantau Pemilu (KIPP) Indonesia, KoDe Inisiatif, CORRECT dan PUSaKO UNAND

\section{Pentingnya Pengawasan Partisipatif dalam Menangani Pelanggaran Pemilu}

Sebagaimana diketahui, penyelenggara pemilu terdiri dari Komisi Pemilihan Umum (KPU), Badan Pengawas Pemilu (Bawaslu) dan Dewan Kehormatan Penyelenggra Pemilu (DKPP). Ketiga lembaga inilah yang menerjemahkan undang-undang dan melaksanakannya dengan asas asas berkeadilan dan setara. KPU sebagai pelaksanaan pemilihan umum tentu mendapat porsi perhatian yang lebih besar dalam pengawasan. Akan banyak pihak yang berkepentingan untuk menjadikan KPU dan Bawaslu sebagai koasi kekuasaannya. Dalam tahap inilah diperlukannya pengawalan pada setiap tahapan penyelenggaraan.

Adapun mekanisme pengawasan pemilu tertuang dalam peraturan bersama KPU, Bawaslu dan DKPP Nomor 13 Tahun 2012, Nomor 11 Tahun 2012 dan Nomor 1 Tahun 2012 tentang "Kode Etik Penyelenggara Pemilu". Peraturan ini menjadi dasar bagi masyarakat untuk membantu mengawal proses pemilihan umum dengan penuh tanggung jawabnya dan berkeadilan.

Pada Pemilu 2014 diwarnai dengan berbagai macam Mal Praktek Pemilu. Dalam demokrasi mal praktek pemilu ibarat penyakit yang menggerogoti demoratisasi dan integritas pemilu tersebut. Karena mal praktek pemilu dapat menurunkan legitimasi pemilu dan kepercayaan publik dan pada akhirnya akan menjadi penyebab menurunnya partisipasi pemilih. Namun menurut Pippa Norris (2012: 00), yang menyatakan bahwa tingkat mal praktek pemilu bergantung pada kualitas dari demokrasi suatu negara. Dimana akan berdampak pada hasil pemilu itu nantinya kedepan. Ketika peserta dan pelaksana berkoasi dalam mencurangi pemilihan maka akan melahirkan pemimpinpemimpin yang tidak kredibel dan tidak berintegritas.

Menurut Sarah Birch (2012: 14), mal praktek memiliki pengertian proses manipulasi yang terjadi pada setiap keseluruhan proses penyelenggaraan pemilu yang bertujuan untuk kepentingan perseorangan, kelompok atau partai politik dengan menggadaikan kepentingan umum.

Berdasarkan laporan Bawaslu yang dikutip oleh ICW (dalam Perludem, 2016: 87-88), sepanjang pemilu presiden 2014 terdapat dugaan pelanggaran sebanyak 1.238. 
Dugaan Pelanggaran terdiri dari 1.136 dugaan pelanggaran administrasi. Dugaan pelanggaran administrasi tersebut kemudian diteruskan kepada KPU untuk ditindaklanjuti. Sisanya, 81 dugaan pelanggaran pidana dan 21 dugaan pelanggaran kode etik. Dugaan pelanggaran terbanyak menyangkut pelanggaran Pemasangan Alat Peraga Kampanye(APK), Permasalahan Daftar Pemilih Tetap (DPT), politik uang dam kampanye hitam. Untuk lebih jelasnya dapat dilihat dalam tabel berikut ini.

Tabel 1. Laporan Dugaan Pelanggaran Pemilu Pemilu Presiden 2015

\begin{tabular}{lc}
\hline \multicolumn{1}{c}{ Jenis Dugaan Pelanggaran } & Jumlah \\
\hline Pelanggaran Administrasi & 1.136 \\
Pelanggaran Pidana & 81 \\
Pelanggaran Kode Etik & 21 \\
\hline Jumlah & 1.238 \\
\hline
\end{tabular}

Sumber: Laporan Bawaslu

Sementara itu, terkait dengan pemilu Legis-atif 2014, kajian ICW mengutip laporan Bawaslu (dalam Perludem, 2016: 89-90) tentang adanya 4.410 kasus dugaan pelanggaran administrasi. Sebanyak 3.455 merupakan temuan dan 655 laporan. Seluruh dugaan pelanggaran tersebut ditindaklanjuti oleh Bawaslu dan diteruskan ke KPU. Oleh KPU, 3740 (91\%) dugaan pelanggaran ditindaklanjuti. Dugaan pelanggaran pidana sebanyak 137 kasus (66 laporan dan 71 temuan). Semua dugaan pelanggaran pidana yang diterima Bawaslu tersebut diteruskan ke pihak kepolisian. Untuk lebih jelasnya, dapat dilihat dalam tabel di bawah ini.

Tabel 2. Kasus Dugaan Pelanggaran Administrasi dan Tindak Lanjutnya dalam Pemilu Presiden 2014

\begin{tabular}{|c|c|c|}
\hline $\begin{array}{l}\text { Jenis Kasus Dugaan } \\
\text { Pelanggaraan } \\
\text { Administrasi dari } \\
\text { Bawaslu ke KPU }\end{array}$ & Jumlah & $\begin{array}{c}\text { Tindak Lanjut dari KPU } \\
\text { ke pihak kepolisian } \\
\text { Sebagai Dugaan } \\
\text { Pelanggaran Pidana }\end{array}$ \\
\hline Berupa Temuan & 3.455 & 71 temuan \\
\hline Berupa Laporan & 655 & 66 laporan \\
\hline Jumlah & 4.410 & 3.740 ditindaklanjuti \\
\hline \multicolumn{3}{|c|}{$\begin{array}{l}\text { Sumber: Laporan Bawaslu, } 2014 \\
\quad \text { Sementara itu, berdasarkan laporan hasil } \\
\text { survey Rumah Pemilu 2014, masalah-masalah } \\
\text { yang paling sering muncul terkait dengan } \\
\text { pemilu adalah sebagaimana tabel berikut ini: }\end{array}$} \\
\hline
\end{tabular}

Tabel 3. Jenis Masalah yang Paling Sering Muncul dalam Pemilu 2014

\begin{tabular}{|c|c|}
\hline Jenis Masalah & $\begin{array}{l}\text { Jumlah dalam } \\
\text { Persentasi }\end{array}$ \\
\hline $\begin{array}{l}\text { Informasi mengenai prosedur } \\
\text { Pemilu }\end{array}$ & $24 \%$ \\
\hline Proses pendaftaran pemilih & $15 \%$ \\
\hline $\begin{array}{l}\text { validitas hasil pemungutan } \\
\text { suara selama proses rekapitulasi } \\
\text { bertingkat }\end{array}$ & $9 \%$ \\
\hline kelayakan fasilitas TPS & $8 \%$ \\
\hline $\begin{array}{l}\text { kompetensi KPPS, dan informasi } \\
\text { mengenai waktu dan tempat } \\
\text { mencoblos }\end{array}$ & $5 \%$ \\
\hline
\end{tabular}

Selain berbagai kasus pelanggaran dalam pemilu 2014, terdapat masalah pelanggaran pilkada serentak 2015 dari keseluruhan tahapan, sebagaimana dikemukakan oleh Peneliti Perkumpulan untuk Pemilu dan Demokrasi (Perludem), sebagaimana dalam tabel di bawah ini.

Tabel 4. Jenis Pelanggaran dalam Pilkada Serentak 2015

\begin{tabular}{lc}
\hline \multicolumn{1}{c}{ Jenis Pelanggaran } & Jumlah \\
\hline Kekerasan pelaksanaan pilkada & 13 \\
Logistik pilkada & 36 \\
$\begin{array}{l}\text { Pelanggaran pidana dalam } \\
\text { pelaksanaan pilkada, } \\
\text { Pelanggaraan administrasi }\end{array}$ & 54 \\
sengketa pencalonan & 25 \\
\hline \multicolumn{1}{c}{ Jumlah } & 12 \\
\hline
\end{tabular}

Sumber: Pasaribu, 2015.

Beberapa kasus di atas merupakan salah satu potret bagi integritas pemilu dimana praktek tersebut masih saja berlangsung yang nota bene pengawas dan penegak hukum terkait pemilu juga telah diperkuat. Dan bisa jadi kasus di atas merupakan puncak gunung es dimana masih banyak terdapat mal praktek pemilu di akar rumput bangsa ini. Tentu akan menjadi pembahasan menarik ketika kita berfikir bagaimana mengawal agar proses pemilihan yang sudah baik saat ini tidak dinodai semakin besar.

\section{Pengawalan Menuju Pemilu yang Demokratis}

Menurut Kamus Bahasa Indonesia, arti kata "kawal" yaitu penjagaan. Mengawal artinya menjaga; mengiring untuk menjaga 
keselamatan (Pusat Bahasa Depdiknas, 2008: 696-697). Secara terminologi mengawal pemilu berarti bagaimana menjaga proses pelaksanaan pemilu berjalan dengan aman dan selamat sehingga tercapai tujuan dan cita-cita dari negara yang berdemokrasi. Adapun pihak yang dijaga adalah para penyelenggara pemilu yaitu pihak KPU, Bawaslu, DKPP, Partai Politik serta aparat penegak hukum yang tergabung dalam Gakumdu, Gabungan Penegak Hukum Terpadu. Sedangkan sebagai penjaga adalah sistem masyarakat yang telah terbentuk sejak dari pembentukan bangsa ini yaitu Civil Society yang telah menjadi penggerak perjuangan pembebasan bangsa ini dari penjajahan.

Salah satu Civil Society yang dapat mengawal proses pemilihan oleh penyelenggara pemilu adalah lembaga pemantau pemilu. Pelaksanaan pemantau pemilu pada hakikatnya bermakna penglihatan atau melihat sebagian yang bisa kita lihat. Kegiatan ini pada umumnya bisa dilakukan kapan saja, dari mana saja dan dari kelompok masyarakat mana saja.

Unsur-unsur masyarakat yang bisa terlibat dalam pemantauan dan pengawasan di antaranya adalah pemilih, peserta pemilu, lembaga pemantau pemilu, media massa, lembaga swadaya masyarakat, dan organisasi kemasyarakatan. Undang-Undang Pemilu menyatakan tiga pihak yang dapat menyampaikan laporan tentang penyimpangan pemilu, yaitu pemilih, lembaga pemantau pemilu, dan peserta pemilu (Ramadhanil dkk, 2015: 25).

Beberapa pemantau pemilu yang terlibat dalam Koalisi Masyarakat Sipil, antara lain Peneliti Perkumpulan untuk Pemilu dan Demokrasi (Perludem), Jaringan Pendidikan Pemilih untuk Rakyat (JPPR), Komite Independen Pemantau Pemilu (KIPP) Indonesia, KoDe Inisiatif, CORRECT dan PUSaKO UNAND (Simanjuntak, 2018).

Jika dilihat dari partisipasi pemilih dalam melakukan pemantauan sejak Pemilu 1999, jumlah pemantau selalu menurun. Penurunan angka pemantau juga dapat dilihat dari penyelenggaraan pilkada. Dua lembaga pemantau yang berkonsentrasi pada aktivitas pemantauan pemilu dengan mengandalkan relawan seperti Jaringan Pendidikan Pemilih untuk Rakyat (JPPR) dan Komite Independen Pemantau Pemilu (KIPP), mengonfirmasi bahwa terjadi penurunan angka pemantau pemilu dari tahun ke tahun, sebagaimana dapat dilihat dalam tabel di bawah ini.
Tabel 5. Jumlah Pemantau JPPR

\begin{tabular}{|c|c|}
\hline Tahun pemilu & Jumlah Pemantau \\
\hline 1999 & 220.000 \\
\hline 2004 & 140.000 \\
\hline Pilkada & 80.000 \\
\hline April 2009 & 3.000 \\
\hline Juli 2009 & 10.500 \\
\hline 2010 (10 pilkada) & 1.200 \\
\hline 2011 (3 pilkada) & 150 \\
\hline 2012 (3 pilkada) & 1500 \\
\hline 2013 (1 pilkada) & 600 \\
\hline
\end{tabular}

Sumber: Pusat Data JPPR

Dari data tabel di atas, dapat dilihat bahwa terjadi penurunan angka pemantau yang sangat signifikan. Jumlah pemilih yang selalu meningkat, berbanding terbalik dengan jumlah partisipasi pemilih dari pemilu ke pemilu. Begitu juga dengan jumlah pemantau pemilu. Setidaknya fenomena ini terkonfirmasi dari data pemantau pemilu yang dimiliki oleh JPPR dan KIPP Jakarta (sebagai salah satu prototype KIPP di seluruh wilayah Indonesia). Euforia pemantauan Pemilu 1999 yang sangat bergelora, dengan menghadirkan ratusan ribu pemantau pemilu, terasa kian tergerus dengan minimnya angka pemantau pemilu dari KIPP (Ramadhanil dkk, 2015: 26).

Keberadaan pemantau pemilu memang sudahmenjadisalahsatuelemenpenting didalam penyelenggaraan pemilu. Namun dalam banyak aktivitas pemantauan pemilu yang dilakukan, fokusnya memang lebih banyak kepada memantau, mencatat, mendokumentasikan (masih tidak terlalu rapi), dan melaporkan ke pengawas pemilu kalau hasil pantauan tersebut adalah pelanggaran pemilu. Selama ini, aktivitas pemantauan pemilu banyak dilakukan saat kampanye pemilu dan hari-H. Di samping itu, teknis pemantauan dilaksanakan dengan menyiapkan dan melatih pemantau terkait dengan tools pemantauan yang telah disiapkan. Mulai dari apa saja yang akan dipantau, di mana pemantauan dilakukan dan lain sebagainya (Ramadhanil dkk, 2015: 35).

Persoalan lain terkait pemantauan pemilu adalah relasi pengawas dengan pemantau/ masyarakat tidak semulus yang diidamidamkan. Lembaga pengawas pemilu yang diharapkan mampu menfasilitasi masyarakat, justru tidak menutup kemungkinan berhadaphadapan. Beberapa persoalan terkait relasi ini 
dikemukakan Junaidi (2013: 47-50), yakni:

1. Ketertutupan jajaran pengawas pemilu. Beberapa pemantau pemilu menemui kendala, ketika harus berhadapan dan bahkan bekerjasama dengan pengawas pemilu, khususnya di daerah. Masih ditemui lembaga pengawas yang tertutup terhadap keberadaan pemantau pemilu, seperti Sekretaris Jenderal KIPP Indonesia). Meskipun cukup menguntungkan bekerjasama dengan Bawaslu dalam pengawasan, masih ditemui beberapa persoalan di lapangan, dimana tingkat penerimaan Bawaslu Provinsi dan jajarannya terhadap pelibatan publik/pemantau masih kurang baik. Kecenderungannya beberapa daerah justru tidak membuka diri.

2. Kecurigaan pengawas terhadap pemantau pemilu. Praktik di lapangan masih ditemui relasi yang kurang baik antara pengawas pemilu dengan pemantau. Hal ini seperti yang disampaikan Ketua KIPP Jakarta, bahwa "Pemantau yang mestinya difasilitasi atau menjadi partner dalam pengawasan justru menjadi pihak yang dicurigai oleh pengawas tingkat desa. Padahal, pengawas tingkat desa sendiri memiliki keterbatasan yang harusnya bisa dilengkapi dengan kerja partisipasi masyarakat atau pemantau".

3. Kekhawatiran terjadinya persaingan dan benturan antara pengawas dengan pemantau. Persoalan yang hampir sama berupa kekhawatiran persaingan antara pengawas dengan pemantau. Sangat mungkin kekhawatiran ini terjadi, mengingat keduanya memiliki ruang lingkup kerja yang hampir sama yakni mengawasi setiap tahapan pemilu. Perbedaannya, hanya soal kewenangan terhadap tindaklanjutnya saja. Hal ini seperti yang disampaikan oleh Koordinator Nasional JPPR, bahwa pengawas di daerah masih membuat jarak antara pengawas pemilu dengan pemantau. Pengawas pemilu cenderung menilai partisipasi adalah bagaimana pengawas pemilu itu mengajak masyarakat untuk memantau. Mereka mengalami ketakutan, kekuatan dan pengaruhnya akan diambil alih oleh pemantau. Selain itu, benturan itu juga muncul, mengingat Bawaslu dan jajarannya merupakan bagian dari objek pantauan pemantau. Pemantau pemilu juga berkepentingan untuk memastikan proses pengawasan yang dilakukan Bawaslu berjalan dengan baik atau dijalankan sesuai mandat undang-undang.
4. Tidak berjalannya prinsip pelayanan. Keluhan pemantau jika harus berhadapan dengan pengawas pemilu dalam pelaporan dugaan pelanggaran adalah ada beban lebih besar yang harus dijalankan pelapor. Ketika pemilih atau pemantau menemukan dugaan pelanggaran, maka harus melengkapi syaratsyarat laporan seperti bukti dan saksi. Beban ini sesungguhnya sangat berat, tetapi justru diserahkan kepada pelapor. Belum lagi beban ancaman dan intimidasi, jika melaporkan dugaan pelanggaran tertentu.

5. Tidak adanya perlindungan terhadap pelapor. Pemantau atau pemilih berhadapan dengan komunitas atau warga sekitar tempat tinggalnya, jika harus melaporkan kerabat atau bahkan tetangganya. Hal ini menjadi pilihan sulit antara aktif berpartisipasi dengan masyarakat dan menjaga hubungan baik dengan sesama rukun tetangga (RT) ataupun rukun warga (RW).

6. Minimnya informasi soal pengawasan. Bawaslu belum menyediakan informasi yang cukup terkait mekanisme dan prosedur pengawasan, sehingga bisa mudah diakses dan dipahami oleh pemilih.

Persoalan ini yang kemudian mengganggu relasi antara pengawas pemilu dan pemantau atau pemilih, khususnya untuk berpartisipasi dalam pengawasan dan penegakkan hukum Pemilu.

Terkait dengan pemantauan pemilu 2014, mayoritas keberagaman aktivitas dalam pemantauan pemilu 2014 khususnya yang telah dilakukan organisasi masyarakat sipil, masih berfokus untuk mengawal proses dan tahapan pemilu. Selain aktivitas di dalam pemantauan proses tahapan pemilu, beragamnya aktivitas masyarakat sipil fokus kepada pemberian informasi kepada masyarakat terhadap kriteria calon yang baik. Inisiatif ini sempat dilakukan olehICW, Kontras, Walhi, dan beberapa lembaga lain dengan membentuk website bersih2014. net. Beberapa aktivitas masyarakat untuk pemantauan pemilu, misalnya pembentukan Matamassa oleh Aliansi Jurnalis Independen dan iLab. Akan tetapi, dari aktivitas pemantauan pemilu tersebut, sosialisasi kepada masyarakat mengenai tahapan pemilu berjalan dan tentang apa yang akan dipantau belum maksimal kepada masyarakat. Selain itu, pendidikan politik dalam bentuk pemahaman terkait dengan 
tahapan kepemiluan juga belum tersosialisasi dengan baik. Lembaga pemantau lain semisal JPPR dan KIPP, juga tidak terlalu fokus untuk melaksanakan sosialisasi, pendidikan politik, dan tahapan pemilu berjalan kepada masyarakat (Ramadhanil, 2015: 35-36) .

Hasil Kajian JPPR (Ramadhanil, 2015: 36-37), menyebutkan tiga hal tujuan pelibatan dan keterlibatan partisipasi masyarakat dalam melakukan pemantauan proses penyelenggaraan pemilu, yakni: (1) Usaha partisipasi masyarakat dalam mewujudkan pemilu yang dapat berlangsung secara demokratis, sehingga hasilnya dapat diterima dan dihormati oleh semua pihak, baik yang menang maupun yang kalah, terlebih oleh mayoritas warga negara yang memiliki hak pilih; (2) Pemantauan juga termasuk usaha untuk menghindari terjadinya proses pemilu dari kecurangan, manipulasi, permainan serta rekayasa yang dapat menguntungkan pihakpihak tertentu dan merugikan kepentingan rakyat banyak; (3) Usaha untuk menghormati serta meningkatkan kepercayaan terhadap hakhak asasi manusia, khususnya hak-hak sipil dan politik dari warga negara.

Namun dalam pelaksanaannya, hal tersebut kemudian yang menjadi tantangan berat. Komisioner KPU Periode 2012-2017 Hadar Nafis Gumay (dalam Ramadhanil, 2015: 37) mengungkapkan kurangnya pemahaman bahwa pemantauan pasca proses TPS itu penting, dan juga minimnya pengetahuan mengenai "tata cara" dan "apa saja" yang harus dipantau. Menurutnya, Pemantauan pasca-pemungutan dan penghitungan suara merupakan bagian kecil dari proses panjang tahapan pemilu. Tidak banyak pemilih, ataupun pemantau yang paham akan pentingnya melakukan pemantauan terhadap proses setelah pemungutan dan penghitungan suara. Perjalanan suara pasca penghitungan di TPS, adalah hal yang sangat krusial. Proses rekapitulasi di PPS, kemudian bergeser ke PPK, diteruskan ke KPU Kabupaten/Kota, dan kemudian di KPU Provinsi, adalah titik penting yang tidak boleh luput dari pengawasan dan pemantauan publik. Pada proses perjalanan suara tersebut, potensi kecurangan sangat besar. Setidaknya, hal ini terkonfirmasi ketika melihat permohonan sengketa hasil pemilu di pemilihan legislatif 2014.

Terkait dengan pengawasan partisipatif, Paling tidak ada dua kebijakan Bawaslu terkait dengan pelibatan dan partisipasi masyarakat dalam pengawasan, yakni Rencana Strategis Bawaslu Tahun 2010-2014 dan Peraturan Bawaslu Nomor 13 Tahun 2012 tentang Tata Cara Pengawasan Pemilu yang di dalamnya mengatur tentang bentuk-bentuk partisipasi masyarakat.Keduakebijakan inimencantumkan sejumlah upaya Bawaslu dalam melibatkan dan mendorong partisipasi masyarakat dalam pengawasan pemilu (Junaidi, 2013: 27).

Bawaslu dalam rencana strategisnya menyadari sejumlah kelemahan dalam mendorong pelibatan dan partisipasi masyarakat. Kelemahan itu terlihat dalam poin kesepuluh bagian kelemahan menyebutkan bahwa permasalahan yang dihadapi Bawaslu dalam pengembangan konsep partisipasi masyarakat, masih pada tataran "uji coba" atau trial and error. Hal ini disebabkan karena belum adanya model partisipasi pengawasan Pemilu yang bisa menjadi acuan. Kelemahan lainnya juga terlihat darikesiapansumberdayamanusia, sebagaimana ditemukan dalam poin ke-12. Kelemahan yang dihadapi Bawaslu adalah kurangnya kemampuan dan kapasitas internal Bawaslu dalam menanggapi dan mengembangkan model pengawasan partisipatif. Utamanya, berkenaan dengan penyiapan pedoman dan pengaturan yang akan menjadi acuan pelaksanaan pengawasan partisipatif. Berdasarkan kekuatan dan kelemahan tersebut, rencana strategis yang disusun kemudian menetapkan misi Bawaslu yang salah satunya adalah "mendorong pengawasan partisipatif berbasis masyarakat sipil." Dikatakan bahwa keterlibatan masyarakat sipil dalam pengawasan tidak saja akan memperkuat kapasitas pengawasan Pemilu, tetapi juga mendorong perluasan wilayah pengawasan. Bahkan akan memperkuat posisi pengawasan Pemilu sebagai lembaga pengawasan yang berkembang kuat, karena ada representasi dari lembaga negara dan masyarakat sipil. Sekaligus akan menjadi media komunikasi pendidikan politik bagi masyarakat tentang partisipasi dalam Pemilu, terutama berkenaan dengan peran strategis pengawasan dalam mendorong terwujudnya Pemilu yang luber dan jurdil (Junaidi, 2013: 28-29).

Rencana Strategis Bawaslu cukup menggambarkan bahwa partisipasi diperlukan untuk keberhasilan pengawasan, yang kemudian ditindaklanjuti dalam peraturan Bawaslu.

Selain itu, kebijakan yang terkait dengan pengawasan partisipatif juga diperkuat dengan 
adanya Undang-undang Nomor 7 Tahun 2017 tentang Pemilihan Umum, yang membuat terobosan baru dalam hal pemantauan Pemilu. Pemantauan Pemilu di tahun 2016 harus diakreditasi dan terdaftar oleh Komisi Pemilihan Umum, pada tahun 2017 Pemantau pemilu harus memperoleh izin dan terdaftar dari Bawaslu RI. Perubahan Pengaturan terkait Pemantauan Pemilu Undang-Undang Nomor 8 Tahun 2012 tentang Pemilihan anggota Legislatif (pileg) pasal 234 ayat 1, Undang-Undang Nomor 42 Tahun 2008 tentang Pemilihan Presiden (Pilpres) pasal 174 ayat 1 dan Undang-Undang Nomor 1 Tahun 2015 tentang Pemilihan Kepala Daerah (pilkada) pasal 123 ayat 3, terkait dengan persyaratan Pemantau secara duplikasi berbunyi; (1) bersifat independen, (2) mempunyai sumber dana yang jelas dan (3) terdaftar dan memperoleh akreditasi dari KPU, KPU Provinsi atau KPU kabupaten/kota sesuai cakupan wilayah pemantauannya. Sementara itu dalam Undang-Undang Pemilu No. 7 Tahun 2017 pasal 436 ayat 1, Pemantau Pemilu harus memenuhi persyaratan (1) bersifat independen, (2) mempunyai sumber dana yang jelas dan (3) teregristrasi dan memperoleh izin dari Bawaslu, Bawaslu Provinsi, atau Bawaslu kabupaten/kota sesuai dengan cakupan wilayah pemantauannya.

Dengan ketatnya syarat membentuk lembaga pemantau ini, maka diharapkan mampu menjadi motor penggerak pengawal proses pemilihan oleh penyelenggara pemilu dan peserta pemilu. diharapkan dapat mendorong peran aktif masyarakat dalam mengamati, mengawasi dan memantau berbagai persoalan yang rentan terjadi dalam Pemilu/Pemilihan, baik itu pelanggaran administratif, pelanggaran tindak pidana pemilu/pemilihan, maupun pelanggaran kode etik yang rentan dilakukan oleh penyelenggara dan peserta pemilu.

Dalam menindaklanjuti ketentuan tentang pemantau pemilu tersebut, Bawaslu mengembangkan pengawasan partisipatif dimana pengawasan seluruh tahapan penyelenggaraan pemilu melibatkan masyarakat. Bawaslu merekrut masyarakat, bisa dari LSM, mahasiswa dan juga pelajar untuk terlibat dalam pengawasan pemilu.

Dalam hal ini Bawaslu melibatkan civil society sebagai salah satu kontingen dalam pelaksanaan pengawasan yang berintegritas. Pengawasan partisipatif ini direkrut mulai dari pendekatan hirarki melalui perpanjangan tangan Bawaslu yang berada di tingkat kabupaten/ kota, kecamatan dan juga desa/kelurahan, serta pendekatan kultural dengan merekrut mahasiswa, LSM dan juga pelajar. Kemudian mereka diberikan pelatihan/sosialisasi untuk melakukan pengawasan seperti bentuk laporan yang harus disusun jika dianggap adanya indikasi pelanggaran dan tahapan penyelenggaraan pemilu. yang kemudian akan dilaporkan secara berjenjang.

Adapun bentuk kegiatan pengawasan partisipatif yang dilakukan masyarakat dalam proses penyelenggaraan Pemilu, sebagaimana dikemukakan Surbakti (2015 50-51), yaitu meliputi: Pertama, melakukan pendidikan pemilih. Kedua, melakukan sosialisasi tata cara setiap tahapan Pemilu. Ketiga, melakukan pemantauan atas setiap tahapan Pemilu dan menyampaikan penilaian atas Pemilu berdasarkan hasil pemantauan. Keempat, melaporkan dugaan pelanggaran Pemilu baik pelanggaran Kode Etik Penyelenggara pemilu maupun pelanggaran ketentuan administrasi Pemilu dan pelanggaran ketentuan Pidana Pemilu. Kelima, mendaftarkan diri sebagai pemilih dan mengajak pihak lain untuk mendaftarkan diri sebagai pemilih (termasuk mengecek nama sendiri dan anggota keluarga lain dalam Daftar Pemilih Sementara). Keenam, menjadi peserta kampanye Pemilu. Ketujuh, memberikan suara pada hari pemungutan suara, menyaksikan proses penghitungan suara di TPS, menjadi Saksi yang mewakili Peserta Pemilu, dan/atau menjadi anggota KPPS/ PPS/ PPK. Kedelapan, ikut berperan dalam proses pemberitaan tentang Pemilu di media cetak atau proses penyiaran tentang Pemilu di media elektronik. Kesembilan, ikut berperan dalam Lembaga Survey yang melaksanakan proses penelitian tentang Pemilu dan penyebar luasan hasil penelitian kepada masyarakat umum. Kesepuluh, ikut serta dalam proses Penghitungan Cepat (Quick Count) atas hasil Pemilu di TPS dan menyebar-luaskan hasilnya kepada masyarakat. Kesebelas, menjadi relawan untuk memastikan integritas hasil Pemilu dengan merekam dan menyebar-luaskan hasil perhitungan suara di TPS kepada masyarakat melalui berbagai media yang tersedia.

Kegiatan pemantauan atas setiap tahapan Pemilu, menyampaikan pengaduan tentang dugaan pelanggaran Pemilu, kegiatan Peng- 
hitungan Cepat, dan kegiatan merekam dan menyebar-luaskan hasil Pemilu merupakan sebagian kegiatan yang berkaitan dengan pengawasan partisipatif dalam pemilu, yang tujuannya untuk memastikan suara setiap pemilih menjadi bagian dari keputusan KPU tentang hasil pemilu. Kegiatan pengawasan partisipatif ini adalah upaya untuk memastikan setiap pemilih memberikan suara secara cerdas, yang dapat dilakukan oleh pemilih (sendiri atau berkelompok), LSM, lembaga pemantau Pemilu, peserta Pemilu, lembaga survey, mereka yang berkarya di media massa, akademisi, kelompok profesi, dan organisasi kemasyarakatan (Surbakti, 2015: 51).

Dalam pengawasan partisipatif tersebut, masyarakat berhak untuk menyampaikan hasil pemantauan atas pemilu dan menyampaikan pengaduan terkait dugaan pelanggaran pemilu. Masyarakat yang terlibat dalam pengawasan partisipatif ini atas dasar kesukarelaan, sehingga tidak ada honor apa pun yang didapatkan. Mereka bertugas untuk memantau seluruh tahapan penyelenggaraan pemilu, dan kemudian melaporkan sesuai dengan format laporan yang disosialisasikan oleh Bawaslu secara berjenjang.

Laporan pengawasan tersebut harus memenuhi syarat $5 \mathrm{~W}$ (who, why, where, what, when) artinya mengetahui siapa yang melakukan, mengapa, dimana terjadinya, pelanggaran seperti apa dan kapan terjadinya, juga $1 \mathrm{H}$ (how) artinya bagaimana kronologis kejadiannya. Laporan tersebut kemudian akan diteliti dan ditelaah lagi oleh Bawaslu, apakah sudah terpenuhi syarat-syarat sebagai delik aduan. Hal inilah yang kemudian menjadi salah satu parameter demokratis pemilu dilihat dari segi pengawasan. Dengan adanya pelibatan masyarakat, maka akan meminimalisir konflik atas kepercayaan terhadap integritas proses dan hasil pemilu, dan akan semakin meningkatkan legitimasi kepemimpinan politik di negara yang demokratis.

Salah satu tantangan terkait pengawasan partisipatif adalah untuk meningkatkan kemauan masyarakat untuk melaporkan setiap pelanggaran atau kecurangan yang ditemui. Hal ini tentu saja merupakan kerja keras dari Bawaslu untuk mengadakan sosialisasi akan adanya salah satu kewajiban sebagai masyarakat untuk mengawasi setiap tahapan penyelenggaran Pemilu, bukan hanya kewajiban untuk ikut berpartisipasi politik dalam hal ikut memilih saja.
Selainupaya-upayapeningkatankesadaran masyarakat tersebut, juga diperlukan adanya akomodasi dan fasilitasi pengawasan publik oleh komisioner Bawaslu terhadap masyarakat, sehingga bisa membangun jejaring yang kuat sebagai salah satu komponen yang terlibat secara aktif dalam melakukan pengawasan di seluruh tahapan penyelenggaraan pemilu. Peranan masyarakat dalam pengawasan pemilu antara lain memastikan terlindunginya hak politik warga masyarakat dan memastikan terwujudnya pemilu yang bersih, transparan dan berintegritas dari sisi penyelenggara dan penyelenggaraannya serta mendorong terwujudnya pemilu sebagai alat penentuan kepemimpinan politik dan evaluasi kepemimpinan politik.

Pada Pemilu Legislatif dan Pemilu Presiden 2014, Bawaslu menfasilitasi dan mengakomodasi partisipasi masyarakat dalam pengawasan pemilu (pengawasan partisipatif) melalui Gerakan Sejuta Relawan Pengawas Pemilu (GSRPP). Hal ini sejalan dengan semangat dan paradigma baru pengawasan, yaitu Pencegahan Pelanggaran. Bawaslu berupaya mensosialisasikan berbagai regulasi terkait Pemilu kepada masyarakat dan meningkatkan peran aktif masyarakat dalam mengawasi pemilu, dengan harapan bahwa pelanggaran pemilu semakin berkurang karena adanya kesadaran dari masyarakat dan peserta pemilu untuk tidak melakukan pelanggaran (Suak, 2017).

Dengan demikian, Bawaslu yang dipandang oleh beberapa pihak, sebagai lembaga 'pencari kesalahan' diubah cara pandangnya sebagai lembaga yang proaktif melakukan pencegahan dini pelanggaran melalui sosialisasi, pendidikan pemilih dan GSRPP, tanpa melupakan keseriusan dan kesungguhan dalam menangani pelanggaran yang terjadi untuk memberi efek jera bagi para pelanggar-pelanggar hukum/ketentuan yang berlaku (Suak, 2017).

Hal ini merupakan perkembangan yang positif, karena dengan adanya pelibatan masyarakat maka hasil pemilu pun akan lebih dipercaya oleh masyarakat. Sehingga mereka akan berlapang dada menerima penetapan hasil pemilu, baik dari segi partai politik, calon dan juga pemilih.

Pengawas seharusnya independen dan tidak memihak (imparsial) pada salah satu calon atau partai politik peserta pemilu, sehingga pemilu bisa dilaksanakan secara fair dan jujur 
tanpa diskriminasi. Seluruh calon dan partai politik peserta pemilu diperlakukan secara adil dan sama dari segi pengawasan.

Selain pengawasan partisipatif dari publik (masyarakat), partai politik selaku peserta pemilu harus menjadi komponen yang ikut mengawasi jalannya pemilu juga bukan hanya sebagai peserta saja, artinya mereka juga harus memiliki kesadaran untuk menjadi peserta pemilu yang berintegritas dimana tidak melakukan pelanggaran pemilu dengan alasan hanya untuk menang. Menjaga dan mengawasi kaderkadernya agar menjadi kader yang memiliki kesadaran politik bahwa mereka juga sebagai bagian dari masyarakat yang harus ikut serta dalam mengawal integritas proses dan hasil pemilu tersebut, terkait juga dengan saksi di Tempat Pemungutan Suara (TPS) agar saksisaksi tersebut tidak hanya menunggu menerima hasil dari KPPS saja tetapi ikut berperan aktif dalam melakukan rekapitulasi/ penghitungan suara artinya ikut mengoreksi yang salah dan bersinergi dengan KPPS dan juga Pengawas Pemilu Lapangan (PPL).

Partai politik juga harus menyadari fungsinya sebagai alat sosialisasi politik yang harusnya ikut berperan serta untuk membangun asas Luber dan Jurdil di masyarakat sebagai tanggung jawab politiknya terhadap masyarakat.

Selain partai-partai politik, Komisi Pemilihan Umum sebagai lembaga penyelenggara Pemilu dengan Divisi Hukum dan Pengawasannya ikut berperan serta dalam pengawasan tahapan penyelenggaraan pemilu. Hal ini diakomodir dengan diadakannya sosialisasi terhadap semua ketentuan dalam setiap tahapan penyelenggaran pemilu terutama yang sering bermasalah adalah terkait kampanye yaitu jadwal dan juga zona kampanye.

Koordinasi dengan Bawaslu terkait perlunya penekanan terkait kampanye agar dilaksanakan oleh parpol peserta pemilu sesuai dengan ketentuan yang telah ditetapkan tanpa melanggar jadwal dan zona kampanye yang telah ditetapkan.

\section{SIMPULAN}

Berdasarkan pembahasan di atas, dapat disimpulkan pentingnya pengawasan partisipatif dalam mengawal pemilu yang demokratis, yang dapat tercapai apabila :

1. Badan pengawasan pemilu, pemantau pemilu dan masyarakat yang dilibatkan dalam pengawasan tahapan penyelenggaraan pemilu harus bersifat independen dan tidak memihak (imparsial) salah satu satu calon / partai politik peserta pemilu sehingga tidak adanya diskriminasi terhadap siapa pun;

2. Adanya sosialisasi secara masif yang dilakukan oleh Bawaslu untuk membangun kesadaran masyarakat bahwa mereka mempunyai kewajiban untuk mengawal hak pilihnya dalam pemilu dengan cara berpartisipasi dalam pengawasan tahapan penyelenggaraan pemilu dan juga terhadap lembaga-lembaga terkait pemantauan pemilu agar mereka ikut mengawasi tahapan penyelenggaraan pemilu bukan hanya pada hari pemungutan suara saja;

3. Adanya persepsi yang sama antara Bawaslu dan pihak-pihak yang tergabung dalam sentra Gakkumdu (Penegakkan Hukum Terpadu) terkait jenis-jenis pelanggaran pemilu dan mekanisme penindakannya;

4. Partai politik juga harus memberdayakan saksi-saksi mereka di Tempat Pemungutan Suara (TPS) terkait pengawasan pada saat rekapitulasi penghitungan suara agar tidak terjadi salah penghitungan suara seperti kesalahan dalam menuliskan jumlah suara pada form Model C1;

5. Partai politik juga aktif mengingatkan kader-kadernya untuk menjalankan hak-hak politiknya secara jujur dan adil;

6. Sinergitas antara Bawaslu dengan Komisi Pemilihan Umum dan pihak terkait dalam Hal Pengawasan Seperti Penertiban kampanye dan alat-alat peraga kampanye.

Dengan adanya peranan aktif dari Bawaslu, Lembaga-lembaga pemantau pemilu dan juga masyarakat dalam mengawasi pemilu, akan memberikan kesadaran bagi para pelaku politik, penyelenggara pemilu dan stakeholder terkait untuk menjaga diri, menjaga marwah partainya sehingga akan tetap berada pada relnya sesuai dengan porsinya masing-masing, yang pada akhirnya akan melahirkan suatu pemilu yang demokratis.

Dengan adanya partisipasi seluruh pemangku kepentingan dalam pengawasan tahapan penyelenggaraan pemilumaka diharapkanakan dapat menghasilkan pemilu yang demokratis baik dari prosesnya maupun hasilnya. 


\section{DAFTAR PUSTAKA}

Badan Pusat Statistik. (2016). Statistik Politik. Jakarta: Badan pusat Statistik.

Bawaslu. (2015). Bimbingan Teknis bagi Bawaslu Provinsi dalam rangka Pemilihan Gubernur, Bupati danWalikota Tahun 2015. Diakses pada http://ppid. bawaslu.go.id/sites/default/files/ dokumen\%20berkala/1.\%20MODULPEMILUKADA-2015.pdf. 19 Februari 2018.

Birch, S. (2011). Electoral Malpractice. Oxford: Oxford University Press.

Faktualnews.co. (2018). Pilkada Jombang 2018 Terancam tanpa Pemantau Independen. Diakses pada https://faktualnews.co. 9 Maret 2018.

Junaidi, V. (2013). Pelibatan dan Partisipasi Masyarakat dalam Pengawasan Pemilu. Jakarta: Perkumpulan untuk Pemilu dan Demokrasi (Perludem) Bekerjasama dengan The Asia Foundation (TAF)

Kabar-banten.com. (2018, 4 Februari). Pemantau Pilkada Kota serang Sepi Peminat. Diakses pada https://www. kabar.com. 9 Maret 2018.

Kampuscenter.com. (2016, 11 Juni). 6 Negara Demokrasi Terbesar di Dunia. Diakses pada http://www.kampus center.com. 9Maret 2018.

Krjogja.com. (2017, 15 Oktober). KPU Buka Pendaftaran Pemantau Pemilu. Diakses pada http://krjogja.com.9 Maret 2018

Maxwell, J. A. (1996). Qualitative Research Design: An Interactive Approach. California: SAGE Publications.

Norris, P. (2012). Making Democratic Governance Work: The Impact of Regimes on Prosperity, Welafare and Peace. New York: Cambrigde University Press.

Pasaribu, A. (2015). Perludem Temukan 140 Pelanggaran Pilkada 2015. Diakses padahttps://www.antaranews.com/ berita/534394/perludem-temukan140pelanggaran- pilkada-2015. 15 Oktober 2017.

Perludem. (2016). Kodifikasi Undang-Undang
Pemilu Pembaruan Hukum Pemilu Menuju Pemilu Serentak Nasional dan Pemilu Serentak Daerah. Jurnal 9. Jakarta: Yayasan Perludem. Hlm. 1-291.

Pusat Bahasa Depdiknas, (2008). Kamus Bahasa Indonesia. Jakarta: Departemen Pendidikan Nasional.

Ramadhanil, F., V. Junaidi dan Ibrohim. (2015). Desain Partisipasi Masyarakat dalam Pemantauan Pemilu. Jakarta: Kemitraan bagi Pembaruan Tata Pemerintahan di Indonesia atas kerjasama dengan Perkumpulan untuk Pemilu dan Demokrasi (Perludem)

Republika.co.id. (2017, 29 Agustus 2017). Pemilu 2019 Butuh Lebih dari 800 Ribu TPS. Diakses pada http://nasional. republika.co.id. 9 Maret 2018.

Rumah Pemilu. (2014). Pemilu 2014 di Indonesia Laporan Akhir oleh Rumah Pemilu. Diakses pada http://www. rumahpemilu.com/laporan/RumahPemilu-2014-di-Indonesia-LaporanAkhir-April-2015.pdf.15 Oktober 2017.

Simanjuntak, R.A.(2018). Pengabaian Verifikasi Faktual Dinilai Perilaku Inkonstitusional. Diakses padahttps://nasional.indonews. com/read/1274814/12/pengabaianverifikasi-faktual-dinilai-perilakuinkonstitusional-1516 280702. 19 Februari 2018

Sindonews.com. (2017, 30 Agustus). KPU Tetapkan Pemilih 300 Orang di Tiap TPS. Diakses pada https://nasional. sindonews. com. 9 Maret 2018.

Suak,J.A.(2017).Pengawasan Partisipatif dan Pemantauan Pemilu. Diakses pada http:// manadopost.online.com/read/2017 /07/28/Pengawasan-Partisipatif-danPemantauan-Pemilu/25212. 28 Februari 2018.

Surbakti, R. dan H. Fitrianto. (2015). Transformasi Bawaslu dan Partisipasi Masyarakat dalam Pengawasan Pemilu. Jakarta: Kemitraan bagi Pembaruan Tata Pemerintahan Indonesia

Surbakti, R. (2014). Integritas Pemilu 2014: Kajian Pelanggaran, Kekerasan dan Penyalahgunaan Uang pada Pemilu 
2014. Jakarta: Kemitraan Bagi Pembaruan TataPemerintahan.

Surbakti, R. dkk. (2008). Perekayasaan Sistem Pemilihan Umum: untuk Pembangunan tata Politik Demokratis. Jakarta: Kemitraan Bagi Tata Pemerintahan di Indonesia.

Suswantoro, G. (2016). Pengawasan Pemilu Partisipatif. Penerbit : Erlangga.

Undang-Undang Nomor 42 Tahun 2008 tentang tentang Pemilihan Umum Presiden dan Wakil Presiden.
Undang-Undang Nomor 8 Tahun 2012 tentang Pemilihan Umum Anggota Dewan Perwakilan Rakyat, Dewan Perwakilan Daerah dan Dewa Perwakilan Rakyat Daerah.

Undang-Undang Nomor 1 Tahun 2015 Penetapan Peraturan Pemerintah Pengganti Undang-Undang Nomor 1 Tahun 2014 tentang Pemilihan Gubernur, Bupati, Dan Walikota Menjadi Undang- Undang

Undang-Undang Nomor 7 Tahun 2017 tentang Pemilihan Umum. 